\title{
THE NOTION WEAPON IN ARABIC IDIOMS
}

\author{
Ludmila Torlakova \\ UNIVERSITY OF BERGEN
}

This study presents a group of Arabic idioms that have as at least one of their components a word denoting a weapon. Handling and using weapons together with exploring their potential is one of the primary experiences people have had. Thus it is worthwhile to investigate how 'weaponry' idioms contribute to expanding figuratively the world picture included in the realm of Arabic phraseology. Weaponry idioms are considered here within the framework of general cognitive linguistics and 'conventional figurative language theory' as developed by Dmitri Dobrovol'skij and Elisabeth Piirainen. An attempt is made to test whether this framework can accommodate semantic analysis of Arabic idioms containing the concept weapon. Selected phrasemes denoting situation and behavior are examined in order to look into their semantic structure and type of motivation. Since the majority of the idioms studied have been collected from dictionaries, an attempt is made to present a contemporary evaluation and assessment of their use in Modern Standard Arabic based on Internet sources.

Modern research very often exceeds the limits of a given discipline in an attempt to study a phenomenon from many different aspects and on the basis of vast data. Linguistic studies are more and more often interested in the relations between language and culture, ethnic identity, and history. In this respect some elements of a linguistic system can represent fascinating objects of study because of their very nature. This is especially true of idioms. Idioms are numerous in any language and form an independent and complicated subsystem within the system of the language. Recently scholars have devoted increasing attention to idioms and their complex nature, studying them from lexical, syntactic, semantic, cognitive and cultural aspects as a source of broad extralinguistic information.

It is accepted in the linguistic literature dedicated to figurative language that idioms are the central group of phrasemes (or fixed expressions, or phraseological units $)^{1}$. A definition of a phraseme, gener-

1 The terminology varies considerably in the studies on figurative language and phraseology. See for example recent studies by Alison Wray and Dmitrij Dobrovol'skij. (For the most part, the names of Russian authors are transliter- 
ally agreed upon, includes the following properties: 'A combination of two or more words is phraseological if (1) the words form a unit that cannot be fully explained by the syntactic and semantic regularities of the combination and if (2) the word combination is commonly used by the speech community, similar to the use of a lexeme.'2

This definition of phraseme implies that the most prominent or 'crucial property' of idioms, according to Dimitrij Dobrovol'skij and Elisabeth Piirainen, is their 'semantic irregularity (or idiomaticity), which is closely related to the property of figurativeness. ${ }^{3}$ On the other hand it is widely accepted that most idioms are 'not frozen elements of a language and that they usually are arbitrary only from the point of view of their production, but not from the perspective of their understanding, because most of them are clearly motivated by the underlying structures of knowledge.'4

The majority of phrasemes are metaphorical or metonymical expressions ${ }^{5}$ and this means that the most important and relevant element of the 'content plane' of idioms is the so-called image component, 'a specific conceptual structure mediating between the lexical structure and the actual meaning of figurative units' 6 (idioms). An idiom is a linguistic item formed on a second, higher level of denomination (as opposed to a word) 'to denote its referent not directly but via another concept'. ${ }^{7}$ This

ated here as they appear together with the titles of their works in languages other than Russian. For works in Russian, a slightly simplified version of the Library of Congress system is adopted to facilitate searching, e.g., both Dobrovol'skij and Dobrovol'skiĭ may appear.)

${ }^{2}$ Harald Bürger, Annelies Buhofer, and Ambros Sialm, Handbuch der Phraseologie (Berlin and New York: Walter de Gruyter, 1982), 1, cited in translation in Dmitrij Dobrovol'skij and Elisabeth Piirainen, Figurative Language: Cross-Cultural and Cross-Linguistic Perspectives (Amsterdam: Elsevier, 2005), 31.

${ }^{3}$ Dobrovol'skij and Piirainen, Figurative Language, 31. See also the earlier A. N. Baranov and D. D. Dobrovol'skiū, 'Idiomatichnost' i idiomy' in Voprosy iazykoznaniia, no. 5, 1996, pp. 51-64.

${ }^{4}$ Dobrovol'skij and Piirainen, Figurative Language, 31.

${ }^{5}$ See Zoltán Kövecses, Metaphor: A Practical Introduction (Oxford: Oxford University Press, 2002), 199-213; Murray Knowles and Rosamund Moon, Introducing Metaphor (London and New York: Routledge, 2006), 19-21; and others.

6 Dobrovol'skij and Piirainen, Figurative Language, 4.

${ }^{7}$ Ibid., 17. Cf. also earlier in Veronika Teliia, Russkaia frazeologiia: Semanticheskǐ, pragmaticheskǐ i lingvokul'turologicheskil aspekty (Moscow: Shkola 
ability of an idiom to "combine two different conceptual levels in its semantic structure' 8 is vital for understanding the meaning of idioms and to a great extent determines their pragmatic function in expressing relation, opinion, characterization, and emotional judgment in a way that is dependent on the image they convey. Linguists are interested in the metaphor and the cognitive structure lying behind it, because as Telia puts it, 'Deconstructing a metaphor, we can gain access to cultural data involved in conceptualization and to the world picture that is shared by all members of a language community and reflected in its linguistic signs. ${ }^{9}$ By studying idioms, it is possible to view from another perspective - as it is reflected and preserved in these petrified expressions - the historical experience of a nation, its spiritual and material culture, its attitudes, and its views on life.

For one interested in the semantic and structural description of Arabic idioms, it is intriguing to investigate subsystems formed by idioms that contain constituents belonging to one thematic field. The tradition of such phraseological research in other languages is long. ${ }^{10}$

In the present study I would like to share some observations I have made on a specific group of idioms in the Arabic language - those involving weaponry, as the title suggests. In my representation and analysis of these idioms I will rely on Langlotz's 'hybrid view' of idioms as 'complex, composite word-configurations'. ${ }^{11}$ Idioms as such have mentally the status of units because of their idiomatic meaning. At the same time many of them can be deconstructed, which 'influences their

\footnotetext{
'Iazyki Russkoĭ Kul'tury', 1996), 133-34.

${ }^{8}$ Dobrovol'skij and Piirainen, Figurative Language, 17.

${ }^{9}$ Veronika Telia [Teliia], Natalya Bragina, Elena Oparina, and Irina Sandomirskaya [Sandomirskaia], 'Lexical Collocations: Denominative and Cognitive Aspects', in EURALEX 1994: Proceedings ([Amsterdam]: n.p., 1994), 372; Veronika Teliia, Russkaia frazeologiia, 214-38.

${ }^{10}$ Dmitrij Dobrovol'skij and Elisabeth Piirainen, 'Keep the Wolf from the Door: Animal Symbolism in Language and Culture', in Proverbium: Yearbook of International Proverb Scholarship, 16, 61.; Shi Sia, 'Kitaĭ, kităiskiǐ, kitaets v russkoĭ frazeologii', in Vestnik Moskovskogo Universiteta. ser. 9, Filologiia, no. 2, 2008, 120-26.; Dobrovol'skij and Piirainen, Figurative Language, chapters 9,12 , and 13 .

${ }^{11}$ Andreas Langlotz, Idiomatic Creativity: A Cognitive-Linguistic Model of Idiom-Representation and Idiom-Variation in English (Philadelphia: John Benjamins Publishing Company, 2006), 53.
} 
processing and syntactic flexibility. ${ }^{\prime 2}$ Further in the context of idiom comprehension "literal meanings" are always generated, and then used where applicable,' 13 which can be considered as evidence for what Langlotz calls the 'motivated semantic structure of a number of idioms'. 'While the influence of conceptual metaphor on idiom representation has remained controversial,' he writes, 'it cannot be disclaimed as an important basis for the semantic structuring of idioms.' ${ }^{14}$ Thus the semantic structure of idioms should be seen as a 'restricted set of conceptual operations', ${ }^{15}$ and as the result of rather sophisticated knowledge processing. In another words 'the actual meaning of an iconically motivated figurative unit is always interpreted against the background of the source-target-correspondence, from which people get comprehensible evidence about how the actual meaning presumably has come into being, rather than as a result of a semantic transfer.' 16

Weapons and their use involve important primary experience which can be employed, in turn, through metaphor, simile or metonymy, as a basis for creating more advanced and complicated concepts. Weaponry idioms contribute to conveying in a more vivid and thorough way different 'experiences' and 'snap shots' of reality. Thus to paraphrase George Lakoff and Dmitrij Dobrovol'skij, weapons through the metaphoric structures they participate in are used not only as means of naming but as instruments of conceptualizing the world around us. They can be seen as some of the bricks used in building our 'world knowledge'.

All the idioms I have gathered have as at least one of their constituents a word denoting some type of weapon or part of a weapon. I leave aside idioms that are through one or more of their elements apparently related to the concept of weapon, for example, those containing words denoting acts such as cutting, thrusting, piercing, and the like. Idioms such as nah̆atahu bi-lisānihi - to slander (lit., to carve s.o. with one's tongue),

12 Ibid.

${ }^{13}$ Cristina Cacciary and Sam Glucksberg, 'Understanding Idiomatic Expressions: The Contribution of Word Meanings', in Understanding Word and Sentence, ed. Greg B. Simpson (Amsterdam: North Holland, 1991), 237.

${ }^{14}$ Langlotz, Idiomatic Creativity, 53.

15 Dobrovol'skij and Piirainen, Figurative Language, 164.

${ }^{16}$ Ibid., 165. Cf. Raymond W. Gibbs, Jr., 'Why Idioms Are Not Dead Metaphors', in Idioms: Processing, Structure, and Interpretation, ed. Cristina Cacciari and Patrizia Tabossi (Hillsdale, New Jersey: Lawrence Erlbaum Associates, Inc., 1993), 74. 
qața ${ }^{c}$ l-rahima - to sever the bonds of kinship, break with one's relatives (lit. to cut the womb), ță inun fi l-sinni - very old (lit., having pierced age [with a lance]) are excluded. Likewise excluded are idioms that do not contain a constituent word denoting a weapon but which make use of images related to weaponry such as al-mawtu l- ${ }^{\circ}$ ahmaru violent battle, with heavy bloodshed (lit., the red death), 'așāba $l$ mahazza - to hit the mark, strike home (lit., to find the right place to cut a notch; cf. Lane, s.v.), ghanīmatun bāridatun - easy prey (lit., cold booty), ibnu l-harbi - brave (lit., a son of war)

This investigation starts with the literal meaning of idioms containing words denoting weapons. It proceeds to present how these words are used in the structure of the idioms to express metaphorically (figuratively) other meanings (the combination of two different conceptual levels as mentioned above). This can be called 'source - goal' ${ }^{17}$ analysis, that is, moving from the source domain to the target domain.

One definition of weapon states that 'a weapon is a tool used to apply or threaten to apply force for the purpose of hunting, attack or defense in combat, subduing enemy personnel, or to destroy enemy weapons, equipment and defensive structures. ... In general, they can be defined as the simplest mechanisms that use mechanical advantage (also called leverage) to multiply force.' 18 The huge impact of weapons on human existence and development, from prehistorical times to the present, is undeniable. And the fact that the development of many weapons has spurred development in other areas of technology is well known.

Weapons and warfare are an important part of almost any culture, and Arabic culture is no exception. First, weapons were needed for providing food and survival in an inhospitable environment. Their use was eventually formalized and idealized. The warrior of Pre-Islamic times on his camel or horse, with his bow and arrows, his sword and shield, and his spear, has always been considered a model to be emulated. The image of these courageous men and of their battles and their deeds has been recorded and made immortal in thousands of verses and historical or literary reports, as well as in numerous histories and romances. Robert Elgood in his book on the arms and armor of Arabia remarks that ' $F$. W. Schwartzlose (1886) used pre-Islamic Arabian poetry as the source for a

17 A. N. Baranov and D. O. Dobrovol'skǐ̌, 'Nachalo i konets v russkoř idiomatike', in Logicheskĭ analiz iazyka: Semantika nachala i kontsa, ed. N. D. Arutiunova (Moscow: Indrik, 2002), 28.

18 Wikipedia, 'Weapon', December 4, 2008, http://en.wikipedia.org/wiki/ Weapon (accessed December 11, 2008). 
study of Arabian weaponry and this is a valuable guide. ${ }^{19}$ Another testimony to the significance of weapons is given in a study of the oral poetry of present-day Arabia by Saad Abdullah Sowayan.

Because of the constant struggle against nature and against other men, desert life puts a premium on manly courage and the combative traits of character.... Before the introduction of firearms, the arms of the Bedouins, such as the lance, saber, and coat of mail, along with the horse, allowed full scope for the display of bravery with little loss of life. The Bedouins are fond of single combat because it is spectacular and because it gives the individual warrior an opportunity to distinguish himself. ${ }^{20}$

The Arabic-Muslim civilization, like nearly all civilizations, was established by fire and the sword or, as expressed in an Arabic idiom, $b i$ l-hadìdi wa-bi-l-nāri (lit., with iron and fire), before its intellectual heritage was spread. As David Nicolle notes,

[T]he World of Islam was an area in which dynasties rose and fell in rapid successions as waves of militarily dominant peoples of varying ethnic or cultural origin passed to and from (sic) over, and with a limited effect upon, the bulk of the settled population. The net result has an apparent complexity akin to Islamic decorative art, though like this art the fundamental factors remain both simple and constant. For this reason, if for no other, the study of Islamic Arms and Armour provides a useful canvas on which to illustrate both the complexity and the constancy of medieval Islamic civilization. ${ }^{21}$

Arabic language is a fundamental part of this 'canvas' and so are idioms. They play an important role, as has been pointed out, in the construction of the Arab picture of the world and of reality, and of how these are conceptualized and evaluated.

From a structural and semantic point of view, the use in idioms of words denoting weapons reflects the significance of weapons and the role they have played in the life of the Arabs. From a cognitive and sociological point of view, weaponry idioms also give some idea about

${ }^{19}$ Robert Elgood, The Arms and Armour of Arabia in the 18th-19th and 20th Centuries (Aldershot, Hants, England: Scolar Press, 1994), viii, referring to Swartzlose's work Die Waffen der alten Araber aus ihren Dichtern dargestellt (Leipzig, 1886).

${ }^{20}$ Saad Abdullah Sowayan, Nabati Poetry: The Oral Poetry of Arabia (Berkeley; Los Angeles; London: University of California Press, 1985), 38-39

${ }^{21}$ David Nicolle, Early Medieval Islamic Arms and Armour (Madrid: Instituto de Estudios sobre Armas Antiguas, Consejo Superior de Investigaciones Cientificas, 1976), 12. 
how concepts are related and images are built. They have a particular emotional effect and express a particular judgment in order to produce an expected stronger impact. In general, constituent words and their particular combinations in the metaphoric structure of these idioms can help to identify some of the most fundamental concepts in Arab culture.

The idioms studied here, which have been collected from different sources $^{22}$ and which stem from different periods, are selected on the grounds stated above. This selection is made on two principles: the literal meaning of the expression has (1) to convey an image and (2) to constitute 'additional naming', or an 'additional [not primary] means for naming things, properties, actions, states, events, and the like'. ${ }^{23}$

The idioms are distributed according to the semantic fields of situation and behavior, and then most are analyzed briefly in a way that shows the underlying structure of cultural knowledge and the conceptual base for their motivation. The analysis aims at testing recent theoretical approaches when applied to Arabic idioms having as a constituent a word denoting weapon.

\section{Situational Idioms}

Well represented is a group of idioms that are used to express situations. The kind of situation depends on the image that is evoked by the literal reading of the constituents of the figurative unit. In these idioms the concept weapon is used to build another concept on a higher cognitive level. The new phrase may express a whole spectrum of different connotations and 'entailments of the situation', ${ }^{24}$ which the corresponding single word or direct expression does not possess. Consider the following examples:

(1) nafadha l-sahmu ${ }^{25}$ - the die is cast (lit., the arrow has pierced)

22 al-Maydān̄̄, Majma ${ }^{c}$ al-amthāl; Abu al-Mahāsin al-Abdarī al-Shayb̄̄, Timthāl al-amthāl; Aḥmad Taymūr, Kitāb al-kināyāt al- ${ }^{c} \bar{a} m m i y y a ; ~ A l-M u n j i d ;$ M. E. Sieny, M. A. Hussein, S. A. A. Al-Doush, A Contextual Dictionary of Idioms; Arabic-Russian and Arabic-English dictionaries; V. D. Ushakov, Frazeologiia Korana (Phraseology of the Koran with a summary in English) (Moscow: 'Vostochnaia Literatura' RAN, 1996); J. L. Burchhardt, Arabic Proverbs: The Manners and Customs of the Modern Egyptians (Richmond Surrey: Curzon Press, 1993).

23 Dobrovol'skij and Piirainen, Figurative Language, 18.

24 Langlotz, Idiomatic Creativity, 52.

25 A Google search (December 18, 2008) found 832 cases of this expression, most of them not the idiom in question. (Google results generally are preceded 
(2) sabaqa l-sayfu $l_{-}{ }^{c} a d h l a^{26}$ - there is nothing one can do about it, it is already too late (lit., the sword has anticipated censure)

(3) balagha l-sikkinu $l^{c}{ }^{c} a z m a^{27}$ - the matter has reached a climax, things have come to a head (lit., the knife has reached bone)

(4) wașalati l-sikkīnu calä l-mahazzi 28 - hard times have come (lit., the knife has reached the right place to cut a notch)

(5) maraqa l-sahmu ${ }^{29}$ (mina l-ramiyyati) - the matter is finished, settled (lit., the arrow has passed [through the game])

(6) șārati/inqalabati l-qawsu/l- ${ }^{c} a s \bar{a}$ rakwatan ${ }^{30}$ - the situation has changed (lit., the bow/club has become a [leather] drinking vessel/ coffepot; cf. Lane, Wehr, s.v.)

(7) nabwatu l-qawsi ${ }^{31}$ - loss of interest in s.th. (lit., bouncing of the bow)

(8) lam yabqa fi qawsi șabrī minzac $u n^{32}$ - my patience is at an end

by 'about', which is deleted hereafter for stylistic reasons.) I counted eight cases before repeats made the effort not worth continuing. The matter is complicated in part by the expression often being used in the financial sense of a stock (sahm) reaching a price. Eliminating digits (as words) from the search reduced the number of hits to 203 , but still with only scattered cases of the idiom, while many cases of the financial expression remained. The Google results here and below, it must be stressed, are by no means accurate counts, because of the repetition of links to the same page. But the differences are as a rule so large, that the numbers can often be taken as an indication of the popularity of an idiom in modern Arabic (not just standard Arabic, however, since a number of the texts found are in dialect). There is also no guarantee that all the texts are modern, though most are.

${ }^{26}$ Google (December 18, 2008) found 20,100 cases.

27 Google (December 18, 2008) found 778 cases.

${ }^{28}$ Google (December 18, 2008) found no examples of this idiom with exactly this wording, but it found 162 cases (3rd masc. sing. alone) of the related idiom 'așāba l-mahazza (to hit the point), although the weapon is not mentioned, and this idiom thus cannot be included in our study.

${ }^{29}$ Google (December 18, 2008) found 504 cases of the expression, of which very few were the idiom.

${ }^{30}$ Google (December 18, 2008) found no cases other than dictionary entries.

31 Google (December 18, 2008) found no cases.

32 Google (December 18, 2008) found 1 (one) modern example (www. arabswata. org/forums/showthread.php? $\mathrm{p}=27624)$. 
(lit., in the bow of my patience there is not an arrow left)

(9) qunbulatun mawqūtatun ${ }^{33}$ - a dangerous situation, a ticking bomb (lit., time bomb)

(1-5) The idioms from 1 to 5 above denote situations that are presented as a result of an activity involving different types of weapons. The weapon, which is the agent (logically, 'means') of the action, the active element - whether it is a sword, a knife, or an arrow - has achieved its 'purpose' and has performed the act it was made for. The target domain of the idiom is a grave and irreversible situation. It is made concrete through the evolving image, presented by the literal lexical meanings of the constituents of the expression. It is understood that it is referring to circumstances existing after the use of a deadly weapon. Thus direct 'bodily' experience with weapons, together with some knowledge of the frames ${ }^{34}$ hunt and battle, (and maybe competition), that is, the source frames, motivates the idioms and helps interpret their meanings. It is possible to say that the general metaphorical model reflected in these idioms consists in the purposeful activities of hunting and battle ${ }^{35}$ and the result achieved is underlined. These meanings are to a certain extent predictable, since knowledge of the concept weapon leads to the given semantic result. This type of motivation Dobrovol'skij and Piirainen define as iconic, since its semantic nature 'manifests itself in the relation between literal and figurative readings (both of the whole word string and of the single constituents or parts of the constituents).' 36 They use the term iconic for those types of motivation 'that are based on similarity (in a wide sense) between the entity denoted by the actual meaning and the entity reflected by the underlying image. ${ }^{37}$ Since a metaphor is em-

33 Google (December 24, 2008) found 136,000 cases. I have seen this idiom listed only in Dāwūd, $M u^{c}$ jam, 442.

34 Vyvian Evans gives the following definition of frame: 'A schematisation of experience (a knowledge structure), which is represented at the conceptual level and held in long-term memory and which relates elements and entities associated with a particular culturally embedded scene, situation or event from human experience. Frames include different sorts of knowledge including attributes, and relations between attributes . . . A frame is related to the notion of a domain.' A Glossary of Cognitive Linguistics (Salt Lake City: The University of Utah Press, 2007), 85-86.

35 Cf. Langlotz, Idiomatic Creativity, 152-55.

36 Dobrovol'skij and Piirainen, Figurative Language, 90.

37 Ibid. 
ployed for the semantic reinterpretation in the idioms above (1-5), it is worth mentioning that this similarity can be expressed by the 'principal of fictitiousness', 'as if' (als ob, as in the theory of literary fiction propounded by Hans Vaihinger [1852-1933] $)^{38}$. The situations denoted by the actual meaning of each idiom are as if they were (namely, similar to) the situation denoted by the lexical structure of the idiom. The situation expressed in 2, for example, is as if "the sword has anticipated censure'. Further, the knowledge people possess about such circumstances within the frame of conflict or battle helps them to interpret correctly the idiom's meaning. ${ }^{39}$

Other idioms that belong to the same semantic field do not have these strong meanings of irreversible, doomed state. For example, the next idiom, through the literal reading of the figurative expression presents a situation that has positive, optimistic connotations.

(6) Here the weapon constituent - the bow/club, is used in a symbolic function - enmity, war and hardship. The same symbolic function is possessed by the other constituent, the drinking-vessel/coffepot - friendship, peace, and pleasant life. The contrast of two source concepts that have an important emblematic meaning in the culture produces a new target concept. The idiom's actual meaning is a changed situation. This type of motivation Dobrovol'skij and Piirainen call 'symbolic motivation', ${ }^{40}$ which is based on a special kind of 'cultural knowledge, that is, on the knowledge of cultural symbols' ${ }^{41}$ (I would like to mention another insight made by Dobrovol'skij and Piirainen, which applies to the Arabic weaponry idioms I am analyzing, namely, that the symbolbased motivation is 'metonymical for the most part, whereas iconic motivation is based on metaphor.' 42 )

(7-8) Idioms 7 and 8, together with idiom 5, exist as dictionary items but are used little or not at all, as the searches show, in Modern Standard Arabic. It does not mean that they have to be ignored as examples of how weapons were used to conceptualize experience with certain situations. Idiom 7 is different from the previous ones by its syntactic

\footnotetext{
38 The Philosophy of 'As If': A System of the Theoretical, Practical and Religious Fictions of Mankind [1911], trans. C K Ogden (New York: Harcourt, Brace \& Company, Inc. 1924).

${ }^{39}$ Dobrovol'skij and Piirainen, 95. Cf. Veronika Teliia, Russkaia frazeologiia, 137-38.

40 Dobrovol'skij and Piirainen, Figurative Language, 96.

${ }^{41}$ Ibid., 253.

42 Ibid., 98.
} 
structure - it is a genitive construct where the weapon word is again the subject, but of the mașdar (verbal noun) of the verb nabā. This makes the idiom 'less active', merely registering the fact that is the result situation. Probably it also conveys an image and addresses knowledge that is somehow older and more specific and cannot be used in modern discourse. The same applies to a great extent to idiom 8. It, too, is 'descriptive' and belongs more to a literary style than to 'active use', for example, in journalism.

(9) This idiom, as the results of a Google search show, has a considerably high frequency in modern Arabic discourse. Its actual idiomatic meaning, because of the image created by the literal meanings of the constituents, is appropriate to express a threatening situation. Its motivational base lies obviously in the metaphor of a weapon/bomb/ container filled with an explosive substance intended to produce a devastating effect within a certain amount of time. The expression is different from the rest of the idioms in this semantic field with respect to its syntactic structure. It is an adjective phrase where the passive participle mawqütatun assumes the function of an adjective that adds to the meaning a sense of immanent disaster that cannot be avoided unless the situation described is somehow defused. This Arabic idiom is virtually the same as that used in European languages, being most likely borrowed from English 'time bomb' rather than French 'bombe à retardement'. It cannot be found in older Arabic dictionaries like the rest of the idioms studied here.

\section{Behavioral Idioms}

The semantic field of behavior comprises quite a few weaponry idioms. Consider these examples:

(1) 'akhraja/ ${ }^{\circ}$ afragha $m \bar{a}$ fi $j a^{c} b a t i h i^{43}$ - to reveal one's hidden resources (lit., to empty one's quiver)

(2) țāsha sahmuhu ${ }^{44}$ - to be on the wrong track, bark up the wrong tree, be unsuccessful, fail (lit., his arrow missed the mark)

(3) jama $a^{c} a^{c} u d d a t a h u^{45}$ - to prepare for conflict (lit., to gather one's military equipment)

${ }^{43}$ For statistics on variants of this idiom, see n. 51.

44 Google (December 18, 2008) found 303 cases of țāsha sahmuhu and 164 of the variant țāshat sihāmuhu.

45 Google (December 18, 2008) found 227 cases of جمع عدنه 2 cases of جمعو ا عدتهم and 55 cases of جمت عدنها , 
(4) $\mathrm{rafa}^{c} a$ l-silāha (fì wajhihi) ${ }^{46}$ - to fight s.o., declare enmity (lit., to raise one's weapons)

(5) 'alqā l-silāhha ${ }^{47}$ - to surrender (lit., to throw down one's arms)

(6) $q a^{c}$ qa $^{c}$ atu l-silāhi/l- ${ }^{\circ}$ asliḥati ${ }^{48}$ - the rattling of sabers, threatening with use of force (lit., the clatter of arms)

(7) qalaba zahra l-mijanni ${ }^{49}$ - to give s.o. the cold shoulder, become hostile towards s.o. (lit., to turn the back of the shield to s.o.)

(1) The first idiom is one of a number of variations on the metaphoric use of $j a^{c} b a$, seen most commonly in the phrase $f i j a^{c} b a t i[h i] .{ }^{50}$ A simple Internet search for جعبته produced a great many thousands of examples preceded by the preposition $f i$, although two examples with $\min$ were noted. ${ }^{51}$ Almost all the examples seemed to be metaphoric. These expressions are interesting because one recognizes in them the conceptual metaphors of container and conduit. ${ }^{52}$ They are among the weaponry

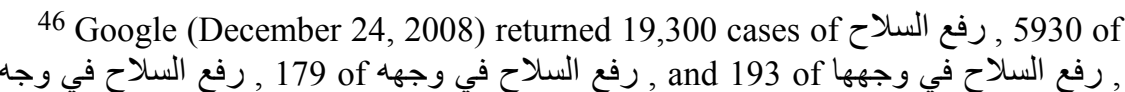
where the pronoun $-h \bar{a}$ most often stands for a government or something similar rather than a female person.

47 Google (December 24, 2008) found 2760 cases of ألقى السلاح , which included examples of ${ }^{\circ} a l q \bar{\imath}$ ( 1 st sing. imperfect and 2 nd fem. sing. imperative), 1730 cases of ألقوا السلاح , ألق السلاح, although it was not possible to determine how many of these were in the metaphorical sense of the expression.

48 Google (December 24, 2008) found 4510 cases of قعقعة السلاح and 188

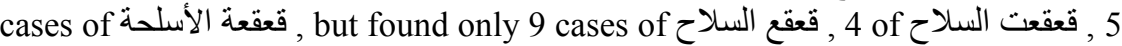

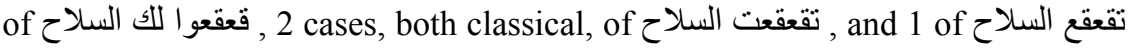
in Ibn Durayd's Jamharat al-lugha.

49 Google (December 18, 2008) found 1170 results using قلب , 1180 using قلب and 1 for قلبو 522 for 3 ق قلبت

50 Cf. Muḥammad Muhammad Dāwūd, Mucjam al-tachīr al-iṣtilāḥ̄ fì l-

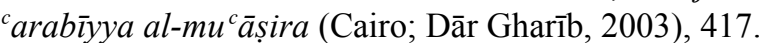

51 162,000 examples in a Google search on December 18, 2008, as well

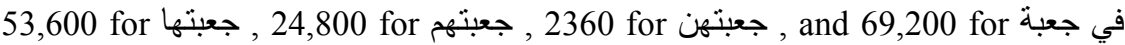
followed by a name or other noun.

52 Michael J. Reddy, 'The Conduit Metaphor: A Case of Frame Conflict in Our Language about Language', in Andrew Ortony, ed., Metaphor and Thought (New York: Cambridge University Press, 1979), 284-324; George Lakoff and Mark Johnson, Metaphors We Live By (Chicago and London: The University of 
idioms often used in modern political discourse precisely because of the many possible understandings of the actual meaning. Its motivational base is specified by the image of and knowledge about a quiver for arrows, which contains dangerous and vitally important objects. It is obvious how the literal meaning of quiver contributes significantly to the idiom's wide use. This idiom is also an example of how motivation can be seen on two different levels by using the 'hybrid' view. The first deep level is the conceptual metaphor, which is the higher level of abstraction. The second level is represented by the concrete image used as the base for the metaphor in this expression. ${ }^{53}$ Here are two similar examples found in the titles of journalistic pieces:

mādhā fì jacbati Ghūl min ziyāratihi l-amīrikiyyati? - What does [Abdullah] Gül bring back from his American visit? (As-Safir, February 10,2007$)^{54}$ :

mādhā fì jacbati l-ra'īsi l-īrānī Nijād li-l-qimmati l-khalījiyyati? What does the president of Iran have up his sleeve for the Gulf Summit? (AlJazeera Talk, February 12, 2007) 55

(2-3) The literal meanings of the constituents of idioms 2 and 3 describe quite common situations involving weapons. These images, and especially the concept weapon - arrow and military equipment, are used to conceptualize behavior through metaphor. The arrow as a source concept in 2 is reinterpreted to mean intentions, aims, and desires, and when it fails to hit the target, metaphorically, it is understood that the person fails to achieve his/her goals or cannot find the appropriate way to fulfill his/her desires. In discourse this idiom can acquire a range of meanings dependent on the context and the entailments of the real situation. Gathering one's military equipment/weapons in 3 can be understood metaphorically and partially metonymically as the source domain

Chicago Press, 1980); and George Lakoff, Women, Fire, and Dangerous Things (Chicago and London: The University of Chicago Press, 1987); cited in Raymond W. Gibbs, Jr., and Jennifer E. O'Brien, 'Idioms and Mental Imagery: The Metaphorical Motivation for Idiomatic Meaning', Cognition 36 (1990): 38.

${ }^{53}$ Cf. Elizabeth Piirainen, "Oblast' metaforicheskogo otobrazheniia" metafora - metaforicheskaia model", in Voprosy iazykoznaniia, no. 4, 1997, p. 95.

${ }^{54}$ Arab Info Center, http://www.arabinfocenter.net/index.php?d=42\&id= 28976 (accessed December 18, 2008).

$55 \mathrm{http} / / / \mathrm{www}$.aljazeeratalk.org/forum/showthread.php?t=88113 (accessed December 18, 2008). 
for the targeted domain of behavior - preparing for conflict, whether it is a real armed conflict, a verbal one, or simply a fight over one's interests.

(4-6) These three idioms have in common that one of the constituents is the word weapon, silähun. In 4 and 5 the verbs $r a f a^{c} a$, 'to raise', and 'alq $\bar{a}$, 'to throw down', are used essentially in their literal meanings, and the expressions picture images that describe symbolically actions that occur when an armed conflict begins or ends. The meaning of each of the two expressions is easy to predict in any context, whether it is used literally or metaphorically. But since both are used primarily in discourse that has nothing to do with armed conflict, it is right to say that the expressions as a whole are reinterpreted in order to convey the actual idiomatic meaning, namely, to begin or cease hostility or hostilities of any kind. Thus the motivational base for these idioms is in the already partially symbolic actions of raising and casting down weapons.

Much of the foregoing analysis of 4 and 5 applies to idiom 6 as well. Being represented in most cases by a genitive construct rather than a verbal sentence, this idiom functions more easily as a predicate. The image of rattling arms while preparing for battle heightens the element of threat and conveys the meaning of the idiom in a especially expressive way.

(7) This idiom is rather widely used because its actual meaning denotes a common situation in life. The image painted by the literal meaning of the constituents - turning the back of the shield to someone is very vivid and expressive. It carries a strong symbolic meaning since a sophisticated object created to protect one from deadly weapons is suddenly turned the wrong way around, which means that someone is left exposed to injury or death. Metaphorically and symbolically the concept of shield used to produce the new concept of hostility towards someone and denying him/her support conveys a powerful meaning with the connotations of the real situation. Again following Dobrovol'skij and Piirainen's theory, I think, it is possible to say that this idiom is both symbolically motivated, based on a special kind of 'cultural knowledge', and at the same time iconically motivated since its actual meaning also is based on metaphor. ${ }^{56}$

\section{Conclusion}

With regard to the semantics of weaponry idioms, it is possible to say that the meanings are within the customary framework of the meanings and semantic fields of other idioms. Weaponry idioms make use of the

\footnotetext{
56 Dobrovol'skij and Piirainen, Figurative Language, 253, 98.
} 
basic, well known qualities and applications of weapons. They do not deal with details of the different weapons. The words denoting weapons and used as constituents in idioms are in fact not many. Generally they comprise the oldest and best known, such as the sword, the bow and arrow, and the knife. The new meanings and concepts created through use of words denoting weapons as constituents cover different topics shared with many other idioms. In this paper only two semantic fields were examined closely, leaving the rest for future study.

In my opinion, many of the weaponry idioms are at least to a certain degree stronger and more expressive owing to the fact that the actions or situations they describe are irreversible, just as the use or misuse of any weapon can be irreversible. Weaponry idioms are highly expressive and the connotations are intense, and thus the resulting impression on the hearer is stronger. The meanings of weaponry idioms have already reached a high level of abstraction. The connection with the basic situation which produced the idiom can still be felt, but many of the idioms have a wide range of applications and plainly are not topically restricted to situations of war or the use of weapons. The majority of the idioms mentioned, if not all, clearly have iconic or symbolic motivation, or both. Indeed a hybrid approach including conceptual metaphor as well as iconic and symbolic motivation seems most appropriate. Despite the metaphorization of the expressions as a whole, or of some of their constituent parts, and notwithstanding the use of metonymy, the concrete image created by the literal reading of the constituents is still detectable. Thus the actual meaning of the idioms is to a great extent predictable. This seems to be explained by the fact that the cultural, encyclopedic knowledge required for interpretation of the images is not ethnically specific. The concept of weapon used in Arabic idioms is easy to grasp and understand. Based on the expressions presented in this paper, it is possible to say that the imagery of weaponry idioms is not very rich. As a source domain weapons offer significant conceptual richness, but the figurative expressions dealt with here do not seem to take advantage of this. Further study of other weaponry idioms and collection of new empirical data, may correct this observation.

The weaponry idioms I have dealt with here form a heterogeneous group in which the different expressions vary considerably with regard to their 'semantic irregularity (or idiomaticity)', a characteristic described by Dobrovol'skij and Piirainen as 'closely related to the property of figurativeness'. ${ }^{57}$ Thus it is possible to argue that the meaning of some

57 Ibid., 31. 
weaponry idioms is so transparent that they can be considered as belonging more to the periphery than to the core category of idioms. For example:

${ }^{\circ}$ alqa $l$-silāha - to surrender (lit., to throw down one's arms)

waḍac a l-silāha fi l- ${ }^{c} a d u w w i$ - to fight s.o. (lit., to place one's arms in the enemy)

Starting from George Lakoff's and Mark Johnson's premise that 'we typically conceptualize the nonphysical in terms of the physical - that is, we conceptualize the less clearly delineated in terms of the more clearly delineated, ${ }^{\prime} 8$ it is possible to see how in many idioms the nonphysical is conceptualized by the clearly delineated concept of weapons or the immediately understandable physical experience with them. Undeniably the use of weapons, especially the most basic of them, was among the earliest physical experiences people had, since they were used in such primordial activities as hunting, raiding, fighting, and contests. It should come as no surprise then that these tools, their characteristics, and their use should become the basis for conveying other subtler and more abstract concepts. According to conceptual metaphor theory, people's understanding of their mental images in idioms is strongly constrained by conceptual mappings between source and target domains. ${ }^{59}$ This theory applies to a good number of the Arabic weaponry idioms discussed here, whose actual meaning can be seen as an interaction between two different conceptual domains where one domain . . . is being structured in terms of the other . . , ${ }^{60}$ for example:

qalaba zahra l-mijanni - to give s.o. the cold shoulder, become hostile towards s.o. (lit., to turn the back of the shield to s.o.)

${ }^{3}$ akhraja/ ${ }^{\circ}$ afragha $m \bar{a} f \grave{\imath} j a^{c} b a t i h i$ - to reveal one's hidden resources (lit., to empty one's quiver)

tăsha sahmuhu - to be on the wrong track, bark up the wrong tree, be unsuccessful, fail (lit., his arrow missed the mark)

nafadha l-sahmu - the die is cast (lit., the arrow has pierced)

${ }^{58}$ Lakoff and Johnson, Metaphors We Live By, 59.

${ }^{59}$ Lakoff and Johnson, Metaphors We Live By; George Lakoff, Women, Fire, and Dangerous Things.

${ }^{60}$ Raymond W. Gibb Jr. and Jennifer E. O'Brien, 'Idioms and Mental Imagery', 64 . 
At the same time looking for abstract cognitive models in such a limited selection within such a limited area as we have drawn on here does not yield satisfactory results and cannot account for all types of idioms. One must take into account many 'different function[s] and different cognitive and communicative value[s]'. ${ }^{61}$ In addition to the knowledge of the underlying conceptual metaphors, there are other types of knowledge that are 'linguistically relevant'. ${ }^{62}$ Therefore culturally based information and concepts included in idioms have to be taken into account, because such information often explains the inference from literal to figurative meaning. For example:

șārati/inqalabati l-qawsu/l- ${ }^{c}$ așa rakwatan - the situation has changed (lit., the bow/club has become a [leather] drinking vessel/ coffeepot)

nabwatu l-qawsi - loss of interest in s.th. (lit., bouncing of the bow)

lam yabqa fì qawsi șabrī minzacun - my patience is at an end (lit., in the bow of my patience there is not an arrow left)

The selection with which I have dealt in this short study is small and gives only limited examples of the amount of information, both linguistic and cultural, that can be gleaned from the store of Arabic idioms related to weaponry. The Google searches and the results they produced are by no means accurate counts, but nevertheless show to some extent how many of the weaponry idioms presented are used in different types of modern Arabic discourse. A future study of the same idioms in context, where they fulfill clearly definable communicative and pragmatic functions, can contribute to their more detailed semantic analysis and interpretation. At the same time, it may be possible to provide plausible explanations for why some weaponry idioms are widely used and others remain only dictionary items.

\footnotetext{
61 Dobrovol'skij and Piirainen, Figurative Language, 142.

62 Ibid., 144.
} 